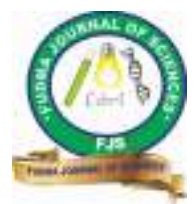

FUDMA Journal of Sciences (FJS)

ISSN online: $2616-1370$

ISSN print: 2645 - 2944

Vol. 4 No. 3, September, 2020, pp $86-92$

DOI: https://doi.org/10.33003/fjs-2020-0403-262

\title{
EFFECTS OF GROUNDNUT (ARACHIS HYPOGEA L) VARIETIES ON THE FLAVOUR PROFILE AND CONSUMER ACCEPTABILITY OF DAKUWA (A CEREAL-GROUNDNUT BASED SNACK)
}

\author{
${ }^{* 1}$ Adekanmi, K. Oladele, ${ }^{2}$ Kazeem, A. Sogunle \\ ${ }^{1}$ Department of Food Technology, Federal College of Freshwater Fisheries Technology, New Bussa, Niger State, Nigeria \\ ${ }^{2}$ Department of Food Science and Technology, Federal University, Dutsin-ma, Katsina State, Nigeria \\ *Corresponding Author's Email: kanmiladele@gmail.com
}

\begin{abstract}
The quality of Dakuwa can be affected by raw materials and processing methods. This work studied the effects of groundnut (Arachis hypogea L.) varieties (Campala, white and Sere) on the colour, flavour profile and sensory properties of Dakuwa. The flavour profile of the Dakuwa samples was analysed with gas chromatography - mass spectroscopy (GC - MS), colour by chroma meter and proximate composition using standard methods while sensory evaluation was done by 25 untrained panelists. The results were analysed using one way analysis of variance. Dakuwa sample with Campala groundnut (DKWC) had the highest concentration of alcohols $(20 \mu \mathrm{g} / 100 \mathrm{~g})$, aldehydes $(86 \mu \mathrm{g} / 100 \mathrm{~g})$, ketones $(1.9 \mu \mathrm{g} / 100 \mathrm{~g})$, heterocyclic aromatic compounds $(11.2 \mu \mathrm{g} / 100 \mathrm{~g})$, and total flavour compounds $(151 \mu \mathrm{g} / 100 \mathrm{~g})$ suggesting higher lipid oxidation and Maillard reaction compared to Dakuwa with Sere and White groundnuts. DKWC had significantly lower L* (lightness) value and significantly higher browning index (84.75) suggesting a higher browning reaction compared to other samples. Sensory evaluation results indicated no significant $(\mathrm{p}>0.05)$ difference in the samples. It can be concluded that any of the three groundnut varieties can be used to produce Dakuwa without altering its sensory qualities.
\end{abstract}

Keywords: Dakuwa, groundnut, flavour profile, sensory quality, browning index.

\section{INTRODUCTION}

Groundnut, also known as peanut, is a leguminous crop planted in almost all the tropical and sub-tropical regions of the world (Arya et al., 2016). Due to its versatility, groundnut is planted in about 100 countries of the world with China, India, Nigeria, and the USA as the leading producers. China produced about $41 \%$, India, $14 \%$ while Nigeria and the USA produced $7 \%$ each of the world groundnut in 2017 (FAOSTAT, 2018). Groundnut is an inexpensive source of high-quality dietary protein $(25-$ 34\%) and oil (47-50\%) (Makeri et al., 2011; Walczyk et al., 2013). The dietary protein is rich in essential amino acids lysine lacking in many kinds of cereal, while the fatty acid contains mostly oleic and linolenic acids (Lykomitros et al. 2016a). Groundnuts can be consumed raw, boiled, roasted, salted, or be processed into groundnut candy or peanut butter (Moss and Otten, 1989). Textured defatted peanut (a potential meat substitute) can also be produced from groundnut (Hinds et al., 2005). Besides, groundnut is used to produce "kunnu gyeda" (a groundnut milk drink), groundnut soup, and Dakuwa (a snack) in Nigeria (Nkama and Gbenyi, 2001; Abdulrahaman and Kolawole, 2003).

The special taste and flavour of foods containing groundnut are important in the acceptance of these food preparations (Asibuo et al., 2008). They provide characteristic flavor and texture to foods as integral diet components (Odoemelam, 2005). Due to its high-quality protein, groundnut has been used to improve the protein level of foods. This has helped tremendously in reducing malnutrition in developing countries (Nkama and Gbenyi, 2001; Ocheme et al., 2011).
Dakuwa is a cereal and groundnut-based snack consumed mainly in the Northern part of Nigeria although it has started gaining popularity in other parts of the country. It could be prepared from an individual or a mixture of cereals (maize, millet, or sorghum), groundnut, ground pepper, ginger, sugar and salt (Nkama and Gbenyi, 2001). The cereal can also be partially replaced by tigernut (Oladele et al. 2009). The ingredients are thoroughly mixed, pounded and molded into balls that can be eaten without further processing (Abdulrahaman and Kolawole, 2003; Ocheme et al., 2013).

The acceptability of Dakuwa by consumers is dependent on many factors including its taste, colour, texture and flavour (Ocheme et al., 2011). In Nigeria, Dakuwa, like other indigenous snack foods, is mainly consumed in its area of production. Its production varies with people, culture, and geographical locations, leading to possession of variable characteristics (Ingbian and Akpapunam, 2005). To date, there has been no standard protocol to produce Dakuwa. However, efforts have been made to study the effects of the quality of raw materials and processing conditions on the quality and consumer acceptability of Dakuwa.

Oladele et al. (2009) reported the effects of substituting maize with tigernut (Cyperus esculentus) on the quality and acceptability of Dakuwa. The effect of maize/groundnut ratio on the quality and acceptability of Dakuwa was reported by Ocheme et al. (2012). Ocheme et al. (2013) studied the moisture sorption characteristics of Dakuwa during storage. Ocheme et al. (2014a) also studied the effect of using malted maize and groundnut on the quality and the effect of $\mathrm{pH}$ on the 
storage stability of Dakuwa. However, information on the flavour profile of Dakuwa and the effects of groundnut variety on the quality characteristics of Dakuwa is scarce in the literature. Thus, this work aimed to determine the physicochemical properties, flavour profiles and consumer acceptability of Dakuwa produced from three varieties of groundnut. The results from this work can serve as a guide in selecting the best groundnut variety in the production of Dakuwa.

\section{MATERIALS AND METHODS \\ Sample Preparation}

Yellow maize and the three groundnuts (Arachis hypogea $\mathrm{L}$.) varieties (Campala, White and Sere groundnuts) used were obtained from a local market in New Bussa, Niger State, Nigeria. The Dakuwa samples were produced following the methods reported by Ocheme et al. (2011). The groundnut samples were sorted, and oven-dried at $70{ }^{\circ} \mathrm{C}$ for $6 \mathrm{~h}$ before roasting in an open pan at $110{ }^{\circ} \mathrm{C}$ (measured a by thermometer) for $20 \mathrm{~min}$ with constant turning. The roasted groundnuts were cooled at ambient temperature $\left(27 \pm 2{ }^{\circ} \mathrm{C}\right)$, peeled manually between palms, and milled into a slurry with a local attrition mill. Maize on the other hand was winnowed and sorted before roasting in an open pan at $110{ }^{\circ} \mathrm{C}$ (measured a by thermometer) for $30 \mathrm{~min}$. The roasted maize was also cooled at ambient temperature $\left(27 \pm 2{ }^{\circ} \mathrm{C}\right)$, sorted to remove the burnt ones, milled into powder and sieved using $212 \mu \mathrm{m}$ sieve. The three groundnut samples were weighed separately before other ingredients were added. The ingredients were measured in their appropriate quantity as follows; groundnut $500 \mathrm{~g}$, maize 1000 $\mathrm{g}$, salt $4 \mathrm{~g}$, sugar $250 \mathrm{~g}$, clove $4 \mathrm{~g}$, and pepper $4 \mathrm{~g}$. The ingredients were well mixed, pounded in a mortar, and molded into small balls manually. The balls were then swirled on a stainless-steel tray to give a smooth appearance. The samples were kept in a freezer $\left(-16^{\circ} \mathrm{C}\right)$ until analyzed.

\section{Proximate analysis}

The crude protein, crude fat, crude fiber and ash content of the samples were determined according to standard AOAC (2005) methods. The moisture content was determined by heating the samples to $103{ }^{\circ} \mathrm{C}$ for $3 \mathrm{~h}$ in an oven, weighed, and reheated until a constant weight was achieved. The carbohydrate conten was calculated by difference $[100-($ moisture + protein + fat + fibre + ash)]

\section{Colour measurement}

A Chroma meter, Model CR-410 series (Konica Minolta Sensing Inc., Japan) was used to measure the colour of the Dakuwa samples. The meter was calibrated with a standard white tile before use. The lightness $\left(\mathrm{L}^{*}\right)$ and chromaticity parameters a* (red-green) and $\mathrm{b}^{*}$ (yellow-blue) of the Dakuwa samples were measured and recorded. The browning index (BI) of the samples was estimated using equations 1 and 2 described by Kumar et al. (2009)

$B I=[100(x-0.31)] / 0.17$

$x=(a+1.75 L) /(5.645+a-3.012 b)$

Where $\mathrm{L}$ - whiteness or brightness/darkness, $\mathrm{a}$ - redness/greenness, $\mathrm{b}$ - yellowness/blueness

\section{Flavour profile analysis}

The gas chromatography-mass spectroscopy (GC-MS) method of Burroni et al. (1997) was used to determine the flavour profile of the Dakuwa samples. Dakuwa samples were ground for approximately $1 \mathrm{~min}$ in a coffee mill. The ground sample was placed in a $10 \mathrm{ml}$ headspace glass tube (Teflon top) and heated at $120{ }^{\circ} \mathrm{C}$ for $30 \mathrm{~min}$ (Young and Hovis, 1990). One milliliter of headspace gas was injected into a Hewlett-Packard Trio-2 VS MASSLAB gas chromatograph/mass spectrometer. A Carbowax $20 \mathrm{M}$ capillary column $(30 \mathrm{~m}$ x $0.25 \mathrm{~mm}$ i.d. $\mathrm{x}$ $0.25 \mathrm{~mm}$ film) was used. The column temperature was programmed from $50{ }^{\circ} \mathrm{C}$ (held for $6 \mathrm{~min}$ ) to $220{ }^{\circ} \mathrm{C}$ $\left(30{ }^{\circ} \mathrm{C} / \mathrm{min}\right.$ ). Injector temperature was $240{ }^{\circ} \mathrm{C}$. The carrier (helium) had a flow rate of $1 \mathrm{~mL} / \mathrm{min}$. Mass spectra were generated at $70 \mathrm{eV}$. The mass spectrometer was scanned from $\mathrm{m} / \mathrm{z} 30$ to 350 at $1 \mathrm{scan} / \mathrm{s}$. The identification of headspace volatile peaks was performed by fragmentation patterns of GC/MS and compared with LAB-BASE (GC/MS Data System). Volatile component levels were estimated based on peak areas (Vercellotti et al., 1992).

\section{Sensory evaluation}

Twenty - five untrained panelists were used for the evaluation of the sensory properties of the Dakuwa samples. The panelists were briefed on the procedure (sniffing with hand for flavour, visual inspection for colour etc.) for sensory evaluation before the test. The sensory qualities evaluated were taste, flavour, texture/consistency, colour, and overall acceptability.

\section{Statistical analysis}

The data obtained after analyses were collated and analyzed using SPSS 16.0 software. One-way analysis of variance (ANOVA) was used to determine the means and the standard deviations while Duncan multiple range test (DMRT) was used to separate the means.

\section{RESULTS AND DISCUSSION}

This work studied the effects of three groundnut varieties on the proximate composition, colour, flavour profile, and consumer acceptability of Dakuwa samples. The composition and the concentrations $(\mu \mathrm{g} / 100 \mathrm{~g})$ of the flavour compounds in Dakuwa samples are shown in Table 1. The flavour compounds in the Dakuwa samples consist of organic acids, alcohols, aldehydes, ketones, and heterocyclic aromatic compounds. Aldehydes are higher in concentration $(71-86 \mu \mathrm{g} / 100 \mathrm{~g})$ compared to other groups of flavour compounds (organic acids, $31-38 \mu \mathrm{g} / 100 \mathrm{~g}$; alcohols, $18-20 \mu \mathrm{g} / 100 \mathrm{~g}$; ketones, $0.6-$ $1.9 \mu \mathrm{g} / 100 \mathrm{~g}$; heterocyclic aromatic compounds, $10-11 \mu \mathrm{g}$ $/ 100 \mathrm{~g}$ ) in the Dakuwa samples. Out of the flavour compounds in the samples, Nonanal had the highest concentration $(30-35$ $\mu \mathrm{g} / 100 \mathrm{~g})$ followed by oxo-methyl ester acetic acid $(23-26$ $\mu \mathrm{g} / 100 \mathrm{~g})$ while 2-Nonanal had the least concentration (0.008 - $0.009 \mu \mathrm{g} / 100 \mathrm{~g})$. Dakuwa sample with Campala groundnut (DKWC) had the highest concentration of alcohols $(20 \mu \mathrm{g} / 100$ g), aldehydes $(86 \mu \mathrm{g} / 100 \mathrm{~g})$, ketones $(1.9 \mu \mathrm{g} / 100 \mathrm{~g})$, heterocyclic aromatic compounds $(11.2 \mu \mathrm{g} / 100 \mathrm{~g})$, and total flavour compounds ( $151 \mu \mathrm{g} / 100 \mathrm{~g}$ ) compared to Dakuwa with Sere groundnut (DKWS) and White groundnut (DKWW). 
Table 1: Concentration ( $\mu \mathrm{g} / \mathbf{1 0 0} \mathrm{g})$ of the flavour compounds in the Dakuwa samples

\begin{tabular}{llll}
\hline Flavour compounds & DKWC & DKWW & DKWS \\
\hline Organic acids & & & 8.05 \\
Acetic acid & 6.12 & 12.29 & 23.11 \\
Oxo-methylester acetic acid & 25.48 & 25.98 & 31.15 \\
Sub total & 31.60 & 38.28 & 9.98 \\
Alcohol & & & 9.63 \\
Ethanol & 8.23 & 10.24 & 19.61 \\
Octanol & 12.04 & 7.96 & 4.77 \\
Sub total & 20.26 & 18.20 & 4.69 \\
Aldehydes & & & 6.82 \\
2-methyl-propanal & 2.99 & 5.93 & 10.86 \\
3-methyl-butanal & 5.14 & 4.51 & 12.19 \\
2-methyl-butanal & 4.66 & 5.34 & 9.05 \\
Pentanal & 12.82 & 7.39 & 2.07 \\
Hexanal & 15.51 & 8.29 & 33.72 \\
Heptanal & 6.25 & 6.86 & 0.009 \\
Benzaldehydes & 2.18 & 1.81 & 0.32 \\
Nonanal & 34.94 & 30.21 & 0.44 \\
2-Nonanal & 0.009 & 0.008 & 84.94 \\
2,4-Decadienal (E, Z) & 0.85 & 0.12 & \\
2,4-Decadienal (E, E) & 0.52 & 0.15 & 0.54 \\
Sub total & 85.87 & 70.61 & 0.82 \\
Ketones & & & 1.36 \\
1-Octan-3-one & 0.56 & 0.08 & 0.86 \\
Heptanone & 1.34 & 0.52 & 1.17 \\
Sub total & 1.89 & 0.59 & \\
Heterocyclic compounds & & & \\
1-methyl-1H-pyrrole & 10.71 & 0.62 & \\
Furfural & 0.52 & 10.13 & \\
Sub total & 11.23 & & \\
\hline
\end{tabular}

The values are mean values of duplicate determination differing with \pm 3 maximum. DKWC $=$ Dakuwa produced with Campala groundnut, $D K W W=$ Dakuwa produced with White groundnut, DKWS = Dakuwa produced with Sere groundnut .

There have been few reports on the effect of raw materials (such as groundnut and maize) and processing conditions on the quality of Dakuwa. Ocheme et al. (2012) reported on the effect of maize/groundnut ratio while Ocheme et al. (2014b) studied the effect of roasting temperature of maize and groundnut on the quality and consumer acceptability of Dakuwa. However, there have been no reports on the flavour profile of Dakuwa. Nevertheless, information exists on the flavour profile of maize (Bredie et al., 1998) and groundnut (Chetschik et al., 2010), the two major raw materials used in Dakuwa production.

The groups of flavour compounds including alcohols, aldehydes, ketones, pyrroles, and furans have been reported in extruded maize meal (Butterly et al., 1994; Bredie et al., 1998) and roasted peanut (Bett and Boylston, 1992; Chetschik et al. 2010) though at different concentrations. Groundnut varieties have been reported to contain flavour compounds different in composition and concentrations (Ku et al., 1998; Baker et al., 2003). Ku et al. (1998) reported a significant difference in the concentration of flavour compounds in two varieties of roasted groundnuts. The flavour compounds in roasted groundnuts (four genotypes) were also reported to be significantly affected by genotype (Baker et al., 2003).

The presence of alcohols, aldehydes, ketones, pyrroles, and furans in the Dakuwa samples suggests that both maize and groundnut contribute to the flavour compounds of Dakuwa.
However, since the same maize sample was used in the preparation of the Dakuwa samples, the difference in the concentration of flavour compounds in the Dakuwa samples suggests that variation in groundnut genotype could be responsible for the flavour difference.

The flavour compounds identified in roasted groundnut have been classified into lipid oxidation products, Maillard reaction products, and others (Bett and Boylston, 1992; Chetschik et al., 2010). The lipid oxidation products could be primary or secondary depending on the compounds formed and the stage of formation of the compounds. The relatively unstable hydroperoxides are the primary lipid oxidation products that can decompose into other compounds depending on the type of cleavage. The secondary lipid oxidation products include organic acids, alcohols, aldehydes, and ketones (Hinds et al., 2005). The Maillard reaction products are the heterocyclic compounds including pyrazines and furans. Other compounds may include Limonene, Naphthalene, and Vinylphenol (Bett and Boylston, 1992; Chetschik et al., 2010; Lykomitros et al., 2016a).

According to Hornostaj and Robinson (2000), Hinds et al. (2005) and Barra et al. (2007), carbonyl compounds such as aldehydes could be derived from either enzymatic or autoxidative decomposition of fatty acids mainly oleic, linoleic and linolenic acids present in groundnuts leading to the formation of carbonyl compounds such as trans-2-heptenal, 
trans-2-hexenal, hexanal, and trans-2-octenal. The lipid oxidation products in the Dakuwa samples such as acetic acid 2-methyl butanal, 3 - methyl butanal, Hexanal, Heptanal, Nonanal, 2,4 - decadienal (E, E), and Heptanone have been reported in different varieties of groundnut (Bett and Boylston, 1992; Chetschik et al., 2010; Lykomitros et al., 2016a) and are known to contribute to the flavour and aroma of various plants and foods (Hornostaj and Robinson, 2006). The aldehydes in the groundnuts might have contributed immensely to the flavour of the Dakuwa samples. The highest concentration of aldehydes in the DKWC samples suggests that autoxidation of lipids was probably highest in the Campala groundnut during roasting compared to other groundnut samples leading to the highest concentration of flavour compounds in DKWC. This could be responsible for the difference in the flavour of the Dakuwa samples.

Organic acids such as acetic acids are known to contribute to the flavour of food products through their mild acidic flavour (Xu et al., 2007). The Dakuwa samples had organic acids concentration ranging from $31-38 \mu \mathrm{g} / 100 \mathrm{~g}$ sample. Although Dakuwa with White groundnut (DKWW) had the highest concentration of organic acids compared to other Dakuwa samples, it had the lowest total flavour concentration. The result suggests a higher contribution of aldehydes to the flavour of Dakuwa samples than organic acids.

Maillard reaction involves the reaction between amino acids and carbohydrates at high temperatures to produce flavour laden products such as furans and pyrazines. The Maillard reaction products in the Dakuwa samples include 1-methyl-1Hpyrrole and furfural. 1-methyl-1H-pyrrole had higher concentration $(9.6-10.7 \mu \mathrm{g} / 100 \mathrm{~g}$ sample) compared to the furfural $(0.41-0.85 \mu \mathrm{g} / 100 \mathrm{~g}$ sample). Dakuwa produced with White groundnut (DKWW) had the lowest concentration of 1methyl-1H-pyrrole and furfural compared to DKWC and DKWS. The results suggest that Maillard reaction products contribute less to the flavour compounds in the Dakuwa samples compared to aldehydes, alcohols, and organic acids.

Strecker degradation, described as the decomposition of amino acids during reaction with carbonyl-containing compounds, into structurally related aldehydes could also occur during roasting (Rizzi, 1999). This could increase the production of aldehydes in roasted samples. The highest aldehyde concentration in DKWC compared to other Dakuwa samples suggests that Strecker degradation probably occurred and was more in the Campala groundnut.

The proximate composition of the three Dakuwa samples is shown in Table 2. The Dakuwa samples are significantly different $(\mathrm{p}<0.05)$ in moisture, crude protein, crude fibre, and ash contents but not significantly different $(p>0.05)$ in fat and carbohydrate. DKWC had significantly $(\mathrm{p}<0.05)$ higher crude protein but lower in moisture content compared to other samples.

The protein content $(24-25 \%)$ of the Dakuwa samples in this study is higher than $13.6-15.26 \%$ reported for traditionally prepared Dakuwa (Ocheme et al., 2011) and 16.5 - 19.1\% reported for Dakuwa samples produced in the laboratory (Ocheme et al., 2014). This may be attributed to the difference in the species of raw materials (including groundnut) used, the level and the type of roasting. Dakuwa is a high protein snack due to the presence of groundnut as one of its main raw materials (Ocheme et al., 2011).

Table 2: Proximate composition of Dakuwa produced from three groundnut varieties

\begin{tabular}{lllllll}
\hline & MC & CP & CF & CFb & Ash & CHO \\
\hline DKWC & $7.41 \pm 0.05^{\mathrm{c}}$ & $25.01 \pm 2.12^{\mathrm{a}}$ & $24.24 \pm 2.01^{\mathrm{a}}$ & $1.62 \pm 0.02^{\mathrm{a}}$ & $2.03 \pm 0.05^{\mathrm{a}}$ & $39.79 \pm 3.03^{\mathrm{a}}$ \\
DKWW & $8.63 \pm 1.03^{\mathrm{a}}$ & $24.62 \pm 2.03^{\mathrm{c}}$ & $24.10 \pm 1.01^{\mathrm{a}}$ & $1.58 \pm 0.00^{\mathrm{b}}$ & $1.98 \pm 0.01^{\mathrm{b}}$ & $39.13 \pm 2.01^{\mathrm{a}}$ \\
DKWS & $7.81 \pm 0.09^{\mathrm{b}}$ & $24.75 \pm 2.15^{\mathrm{b}}$ & $24.17 \pm 2.01^{\mathrm{a}}$ & $1.50 \pm 0.02^{\mathrm{c}}$ & $1.90 \pm 0.01^{\mathrm{c}}$ & $39.84 \pm 3.00^{\mathrm{a}}$ \\
\hline
\end{tabular}

Values are means with standard deviations $(n=3)$. Means with different letters down the columns are significantly different $(P \leq$ 0.05). DKWC = Dakuwa produced with Campala groundnut, DKWW = Dakuwa produced with White groundnut, DKWS =

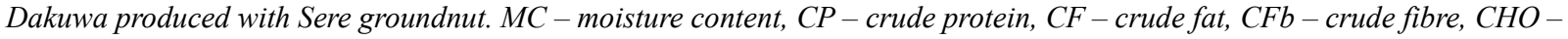
carbohydrates.

a higher level of Maillard reaction and Strecker degradation

Groundnut species had been reported to contain up to $38.6 \%$ protein thus, it is a valuable plant protein source for improving the nutrition of humans and farm animals (Atasie et al., 2009). Groundnut (Ku et al., 1998) and cereal varieties (Zhou et al., 1999) may differ in composition and reaction to processing. Amino acids, the monomeric units of proteins, are key partners in flavor formation and contribute to the flavour of roasted foods (Rizzi, 1999). Amino acids react with sugars at high temperature to produce both stable and unstable flavor compounds through the Maillard reaction. The unstable compounds may strike the unreacted amino acids and decompose it to structurally related aldehydes (Strecker degradation) (Rizzi, 1999) that could increase the flavor content of roasted foods. Although the carbohydrate content of the Dakuwa samples is not significantly different ( $\mathrm{p}>0.05)$, that probably resulted in higher flavour content compared to

the higher protein content of DKWC suggests the possibility of

other samples.

The roast colour of the Dakuwa samples as measured by L*, a* and $\mathrm{b}^{*}$, and the browning index is shown in Table 3. Sample DKWC had significantly lower $(p<0.05) L^{*}$ value $(47.10)$ while sample DKWS had significantly higher $(\mathrm{p}<0.05) \mathrm{a}^{*}$ value $(8.33)$ and significantly lower $(p<0.05) b^{*}$ value $(23.45)$ compared to other samples. The $\mathrm{L}^{*}, \mathrm{a}^{*}$, and $\mathrm{b}^{*}$ values represent the lightness or darkness with values ranging between 0 (black) and 100 (white), redness or greenness, and yellowness or blueness of the samples respectively. DKWC had a significantly higher $(\mathrm{p}<0.05)$ browning index, BI, (84.75) compared to DKWW (74.02), and DKWS (53.22). 
Table 3: $L *$ (lightness/darkness), $a *$ (redness/greenness) and $b *$ (yellowness/blueness) values and the browning index of the Dakuwa samples produced from three groundnut varieties

\begin{tabular}{lcccc}
\hline Sample & $\mathrm{L}^{*}$ & $\mathrm{a}^{*}$ & $\mathrm{~b}^{*}$ & $\mathrm{BI}$ \\
\hline DKWC & $47.10 \pm 3.04^{\mathrm{c}}$ & $8.06 \pm 0.01 \mathrm{~b}$ & $24.79 \pm 1.04 \mathrm{a}$ & $84.75 \pm 2.02 \mathrm{a}$ \\
DKWW & $51.29 \pm 3.04^{\mathrm{b}}$ & $7.10 \pm 0.03 \mathrm{c}$ & $24.70 \pm 1.02 \mathrm{~b}$ & $74.02 \pm 2.34 \mathrm{~b}$ \\
DKWS & $65.17 \pm 4.03^{\mathrm{a}}$ & $8.33 \pm 0.03 \mathrm{a}$ & $23.45 \pm 2.02 \mathrm{c}$ & $53.22 \pm 2.41 \mathrm{c}$ \\
\hline
\end{tabular}

Values are means with standard deviations $(n=3)$. Means with different letters across the rows are significantly different $(P \leq$ 0.05). DKWC = Dakuwa produced with Campala groundnut, DKWW = Dakuwa produced with White groundnut, DKWS $=$ Dakuwa produced with Sere groundnut, $L^{*}=$ lightness or darkness, $a^{*}=$ redness or greenness, $b^{*}=$ yellowness or blueness values, BI-browning index.

Many researchers including Sanders et al. (1989), Kumar et al. (2009), and Lykomitros et al. (2016a, b) have measured the colour of roasted peanuts using the $\mathrm{L}^{*}, \mathrm{a}^{*}$, and $\mathrm{b}^{*}$ values. Lykomitros et al. (2016a) reported differences in the roast colour ( $\mathrm{L}^{*}, \mathrm{a}^{*}$, and $\mathrm{b}^{*}$ values) of different varieties of peanuts. The authors attributed the difference to the variation in the chemical composition and the degree of browning that occurred in the peanuts during roasting. Sanders et al. (1989) related the $\mathrm{L}^{*}$ value to the maturity of roasted peanut. The authors stated that roasted matured peanuts have higher $\mathrm{L}^{*}$ values compared to immature seeds. Kumar et al. (2009) compared the $\mathrm{L}^{*}$ values of infrared roasted peanut to that of sand and drum roasted peanuts and reported that high temperature and elongated roasting time decreased the $\mathrm{L}^{*}$ values of roasted peanuts.

The significantly lower $\mathrm{L}^{*}$ value of DKWC in this work suggests that a higher degree of browning took place in Campala groundnut compared to other groundnuts. This fact is complemented by the significantly higher browning index of
DKWC. During roasting, caramelization and browning reactions occur and result in the formation of brown pigments (Kumar et al., 2009; Lykomitros et al., 2016b). The browning products may add to the roast colour, flavour and antioxidant properties of roasted peanut (Cämmerer and Kroh, 2009; Arya et al., 2016).

Colour is a critical factor used in measuring the roast quality of groundnut and other products (Shakerardekani et al., 2011; Lykomitros et al., 2016a). Aside from contributing to the development of flavour and aroma, the roasting conditions of the groundnut can also affect the colour of products. Oladele et al. (2009) stated that the flavour, colour and the ingredients used can determine the consumer acceptability of Dakuwa.

Although, a significant difference was observed in the $L^{*}$ values and the browning index of the Dakuwa samples, sensory evaluation results (Table 4) showed no significant difference $(\mathrm{p}>0.05)$ in the taste, flavor, consistency, colour and overall acceptability of the samples probably due to the inability of the sensory panel to detect the small change in the products.

Table 4: Sensory scores of the Dakuwa samples produced from three varieties of groundnut

\begin{tabular}{llllll}
\hline Sample & Taste & Flavour & Consistency & Colour & $\begin{array}{l}\text { Overall } \\
\text { acceptability }\end{array}$ \\
\hline DKWC & $3.40 \pm 1.12$ & $3.40 \pm 0.99$ & $3.80 \pm 1.01$ & $3.13 \pm 0.92$ & $3.60 \pm 0.83$ \\
DKWW & $3.67 \pm 1.11$ & $3.40 \pm 0.18$ & $3.40 \pm 0.91$ & $3.07 \pm 1.22$ & $3.67 \pm 0.72$ \\
DKWS & $3.60 \pm 0.99$ & $2.93 \pm 0.89$ & $3.33 \pm 1.07$ & $3.20 \pm 1.32$ & $3.20 \pm 1.08$ \\
\hline
\end{tabular}

Values are means with standard deviations $(n=25)$. Means with different letters down the columns are significantly different $(P \leq$ 0.05). DKWC = Dakuwa produced with Campala groundnut, DKWW = Dakuwa produced with White groundnut, DKWS $=$

Dakuwa produced with Sere groundnut.

\section{CONCLUSIONS}

Dakuwa produced from Campala, Sere and white groundnuts seem not to be different in flavor profile and sensory properties. It can be concluded that any of the groundnut variety can be used for Dakuwa production without compromising quality and acceptability.

\section{REFERENCES}

Abdulrahaman, A. A. and Kolawole O. M. (2003). Traditional preparation and uses of maize in Nigeria. African Journal of Biotechnology 4(3): 1-5

AOAC (2005) Official methods of Analysis (17th Ed) Association of Official Analytical Chemist, Washington, D.C. USA.

Arya, S. S., Salve, A. R. and Chauhan, S. (2016). Peanuts as functional food: A review. Journal of Food Science and
Technology, 53(1): $31-41$.

Asibuo, J. Y., Akromah, R., Safo-Kantanka, O., Osei, A., Hanskofi, O. S., and Agyeman, A. (2008). Chemical composition of groundnut (Arachis hypogea L) landraces. African Journal of Biotechnology, 7(13): 2203 - 2208.

Atasie, V. N., Akinhanmi, T. F. and Ojiodu, C. C. (2009). Proximate analysis and physicochemical properties of groundnut (Arachis hypogaea L.). Pakistan Journal of Nutrition, 8(2):194 - 197.

).

Baker, G. L., Cornell, J. A., Gorbet, D. W., O’Keefe, S. F., Sims, C. A. and Talco, S. T. (2003). Determination of pyrazine, and flavour variations in peanut genotypes during roasting. Journal of Food Science, 68(1): 394 - 400. 
Barra, A., Baldovini, N., Loiseau, A. M., Albino, L., Lesecq, C. and Lizzani - Cuvelier, L.

(2007). Chemical analysis of French beans (Phaseolus vulgaris L.) by headspace solid-phase microextraction (HS-SPME) and simultaneous distillation/ extraction (SDE). Food Chemistry, 101: $1279-1284$.

Bett, K. L. and Boylston, T. D. (1992). Effect of storage on roasted peanut quality: Descriptive sensory analysis and gas chromatographic techniques. In: Lipid oxidation in food, Ed. S. Angelo, ACS symposium series; American Chemical Society, Washington DC. Pp $322-343$.

Bredie, W. P., Mottram, D. S. and Guy, R. C. E. (1998). Aroma volatiles generated during extrusion cooking of maize flour. Journal of Agricultural and Food Chemistry, 46: 1479 - 1487.

Burroni, L.V., Grosso, N.R. and Guzman, C.A. (1997). Principal volatile components of raw, roasted, and fried Argentinean peanut flavors. Journal of Agricultural and Food Chemistry, 45:3190 - 3192.

Butterly, R. G., Stern, D. J. and Ling, L. C. (1994). Studies on flavour volatiles of some sweet corn products. Journal of Agricultural and Food Chemistry, 42: 791 - 795.

Cämmerer, B. and Kroh, L. W. (2009). Shelf life of linseeds and peanuts in relation to roasting. $L W T-$ Food Science and Technology, 42: 545 - 549 .

Chetschik, I., Granvogl, M. and Schieberle, P. (2010). Quantitation of key peanut aroma compounds in raw roasted and pan-roasted peanut meal. Aromaa reconstitution and comparison with commercial peanut products. Journal of Agricultural and Food Chemistry, 58: 11018 - 11026.

FAOSTAT (2018). Statistical database of the Food and Agricultural Organisation of the United

Nations. Online. Rome: FAO. http://faostat.fao.org.

Hinds, M. J., Riaz, M. N., Moe, D. and Scott, D. D. (2005). Fatty acid and volatile flavour profiles of textured partially defatted peanut. In: Food Lipids, Ed. F. Shahidi, ACS symposium series, American Chemical Society. Washington, DC. $P p 205-219$.

Hornostaj, A. R., and Robinson, D. S. (2000). Purification of hydroperoxide from pea seeds. Food Chemistry, 7(2):241 247.

Ingbian, E. K. and Akpapunam, M. A. (2005). Appraisal of traditional technologies in the processing and utilization of 'mumu' a cereal-based local food product. African Journal of Food, Agriculture, Nutrition and Development, 5 (2): 11 - 15.

Ku, K. L., Lee, R. S., Young, C. T. and Chiou, Y. Y. (1998) Roasted peanut flavour and related compositional characteristics of peanut kernels of spring and fall crops grown in Taiwan. Journal of Agricultural and Food Chemistry, 46: $3220-3224$

Kumar, S., Debnath, S. and Hebbar, U. H. (2009). Pulsed infrared roasting of groundnuts and its quality. International Journal of Food Engineering, 5(4): 1 - 19.

Lykomitros, D., Fogliano, V., and Capuano, E. (2016a). Flavour of roasted peanuts (Arachis hypogea) - Part 1: Effect of raw material and processing technology on flavour, colour and fatty acid composition of peanuts, Food Research International, 89: 860 - 869 .

Lykomitros, D., Fogliano, V. and Capuano, E. (2016b). - Part II: Correlation of volatile compounds to sensory characteristics. Food Research International, 89: 870 - 881.

Makeri, M. U., Bala, S. M., and Kassum, A. S. (2011). The effects of roasting temperatures on the rate of extraction and quality of locally-processed oil from two Nigerian peanut (Arachis hypogea L.) cultivars. African Journal of Food Science, 5(4): 194 - 199.

Moss, J. R. and Otten, L. (1989). A relationship between colour development and moisture content during roasting of peanuts. Canadian Institute of Food Science and Technology Journal, 22(1):34-39.

Nkama, I. and Gbenyi, D. I. (2001). The effect of malting of millet and sorghum on the residual phytates and polyphenols in 'dakuwa' - a Nigerian cereal-legume snack food. Nigeria Journal of Tropical Agriculture, 3:270 - 275.

Ocheme, O. B., Ariahu, C. C. and Igyor, M. A. (2011). Assessment of traditionally produced dakuwa (a cereal/legumebased Nigerian snack). Nigerian Food Journal, 29:63 - 69.

Ocheme, O. B., Ariahu C. C. and Ingbian, E. K. (2012). Effect of maize groundnut ratio on the acceptability of dakuwa - a Nigerian cereal/groundnut snack. Nigerian Journal of Nutritional Science, 33(1):18 - 22.

Ocheme, O. B., Ariahu, C. C. and Ingbian, E. K. (2013) Moisture sorption characteristics of dakuwa (Nigerian cereal/groundnut snack) International Journal of Food Engineering, 9(4): 499 - 504.

Ocheme, O. B., Ariahu, C. C., Ingbian, E. K. and Igbabul, I. B. (2014a). prediction of shelf life of Dakuwa (Nigerian cereal/groundnut snack) using $\mathrm{pH}$ as an index of acceptability. Food Science and Quality Management, 24:16 - 23.

Ocheme, O. B., James, S., Baba-Ibrahim, A., Mohammed, M. M. and Nuraini, A. (2014b). Effect of roasting temperature on the quality and acceptability of Dakuwa. Journal of Biology, Agriculture and Healthcare, 4(18):11 - 15.

Odoemelam, S. A. (2005). Proximate composition and selected physicochemical properties of the seeds of African oil bean (Pentaclethra macrophylla). Pakistan Journal of Nutrition, 4: $382-383$.

Oladele, A. K., Ibanga, U. I. and Adebesin, O. L. (2009) Effect of substituting maize with tigernut on the quality and acceptability of "Dakuwa". In the proceedings of the $33^{\text {rd }}$ Annual Conference of Nigerian Institute of Food Science 
and Technology (NIFST), Nigeria. pp $97-98$.

Rizzi, G. P. (1999). The Strecker degradation and its contribution to food flavour. In: Teranishi, R., Wick, E. L., Hornstein, I. (eds). Flavour Chemistry, Springer, Boston, MA

Sanders, T. H., Vercellotti, J. R., Crippen, K. L. and Civille, G. V. (1989). Effect of maturity on roast colour and descriptive flavour of peanuts. Journal of Food Science, 54(2): 475 - 477.

Shakerardekani, A., Karim, R., Mohd Ghazali, H. and Chin, N. L. (2011). Effect of roasting conditions on hardness, moisture content and colour of pistachio kernels. International Food Research Journal, 18: 723 - 729.

Vercellotti, J. R.; Crippen, K. L.; Lovegren, N. V. and Sanders, T. H. (1992). Defining roasted peanut flavor quality. Part 1. Correlation of GC volatiles roast color as an estimate of quality. In: Food Science and Human Nutrition, Ed. G. Charalambous, Elsevier Science Publishers: Amsterdam, pp $183-209$.
Walczyk, N. E., Smith, P. M. C., Tovey, E., Wright, G. C., Fleischfresser, D. B. and Roberts, T. H. (2013). Analysis of crude protein and allergen abundance in peanuts (Arachis hypogea cv. Walter) from three growing regions in Australia. Journal of Agricultural and Food Chemistry, 61: 3714 - 3725.

Xu, Y., Fan, W. and Qian, M.C. (2007). Characterization of aroma compounds in apple cider using solvent-assisted flavor evaporation and headspace solid-phase microextraction. Journal of Agricultural and Food Chemistry, 55: 3051 - 3057.

Young, C. T. and Hovis, A. R. (1990). A method for the rapid analysis of headspace volatiles of raw and roasted peanuts. Journal of Food Science, 55: 279 - 280.

Zhou, M., Robards, K., Glennie-Holmes, M. and Helliwell, S. (1999). Analysis of volatile compounds and their contribution to flavour in cereals. Journal of Agricultural and Food Chemistry, 47(10): 3941 - 3953.

(C)2020 This is an Open Access article distributed under the terms of the Creative Commons Attribution 4.0 International license viewed via https://creativecommons.org/licenses/by/4.0/ which permits unrestricted use, distribution, and reproduction in any medium, provided the original work is cited 